\title{
Reservoir Fish Stocking: When One Plus One May Be Less Than Two
}

\author{
Angelo Antonio Agostinho1,*, Fernando Mayer Pelicice ${ }^{2}$, \\ Luiz Carlos Gomes ${ }^{1} \&$ Horácio Ferreira Júlio Jr. $^{3}$
}

\author{
${ }^{1}$ Nupélia, Departamento de Biologia, Pós-graduação em Ecologia de Ambientes Aquáticos Continentais, \\ Universidade Estadual de Maringá - UEM \\ ${ }^{2}$ Neamb, Pós-graduação em Ecologia de Ecótonos, Universidade Federal do Tocantins - UFT \\ ${ }^{3}$ Nupélia, Departamento de Biologia Celular e Genética, Pós-graduação em Ecologia de Ambientes Aquáticos Continentais, \\ Universidade Estadual de Maringá - UEM
}

\begin{abstract}
Fisheries management in Brazilian reservoirs is based (since the 1970's) on stocking and construction of fish passes. Low landings of the fisheries and the precarious conservation status of native populations in the Upper Paraná River basin indicate how useless these practices were. Failures in most stocking programs conducted may be explained by the negligence of basic assumptions for implementation (clear goals, scientific foundation and evaluation of results). In spite of the common sense support, decision makers should consider that, for any management actions involving biomanipulation, there are relevant environmental risks related to the origin and selection of broodstock and production of fries, and to the releasing of reared fish. Among the latter should be mentioned introduction of associated non-native species (pathogens and parasites), genetic degradation of native stocks (bottleneck effects, loss of genetic variability and fitness, domestication), imbalances and changes in community structure. For an environmental friendly and economical and societal desirable stocking, the decision process should consider information on the receptor ecosystem, target species, uses and users of the resource, legislation and risks for biodiversity conservation. Therefore, the first aspect to be considered is the need for stocking and identification of environmental constrains to it. The ability to produce fish with genetic quality equivalent to native stock and with unaltered ability to spawn in nature (the main challenges in the stocking process) should also have decisive roles in determining whether a stocking program should be implemented. Size, quantity, season and site of releasing should be based on the life cycle, distribution and structure of natural populations, whereas evaluation and monitoring should be considered as integral and indissoluble parts of the stocking process. Habitat management and fishery control should be considered as alternatives or complements. Impoundments are sources of impacts on biodiversity and the success of stocking in such environments appears temporary. Ideally, the success should be quantified by the ability of stocked fish to reproduce in nature and to contribute to the genetic variability of the population. For ethical conservation reasons stocking cannot be only evaluated through fishery landings.
\end{abstract}

Key words: Fishery Management, Exotic Species, Native Stocks, Fish Reproduction, Brazil.

\section{Introduction}

The building of hydroelectric dams has profoundly changed the landscape in South American river systems by altering the quality and availability of habitats as well as the water dynamics. These changes exert strong selective pressure on pre-existing aquatic communities because not all species can colonize or maintain self-sustaining populations in

\footnotetext{
*Send correspondence to: Angelo Antonio Agostinho Nupélia, Departamento de Biologia,

Pós-graduação em Ecologia de Ambientes Aquáticos Continentais, Universidade Estadual de Maringá - UEM Av. Colombo 5790, bloco H-90, CEP 87020-900, Maringá, PR, Brazil

E-mail: agostinhoaa@gmail.com
}

this new system (Agostinho et al. 2008). In addition, given the evolutionary past of South American fish, which have occurred in a predominantly lotic environment, species with pre-adaptation (sensu Fernando \& Holcik 1991) in lacustrine or pelagic environments are rare (Agostinho et al. 2008). Then, several species that require running water (rheophilic species, Gomes \& Miranda 2001) and extensive habitats (migratory species) are particularly vulnerable. These species are generally larger in size and have fishing value (Hoeinghaus et al. 2009).

The perceptions of these impacts are old and it was already manifested by the efforts conducted to mitigate the impacts 
of the first large impoundments in Brazil (e.g., a fish ladder in the Itaipava Dam, Pardo River, in 1911). The mitigation attempts, which were generally focused on the impounded areas, involved the building of fish passes (e.g., ladders) and the installation of hatcheries for managing fish stocks and controlling fishing activity. However, these actions were only recently monitored and the results of the evaluations have indicated that several management initiatives, such as ladders, had adverse effects on the ichthyofauna targeted for conservation (Agostinho et al. 2007a; Pelicice \& Agostinho, 2008; Volpato et al. 2009).

In the context of conservation, stocking efforts are emblematic. Similar to the other management tools, stocking has been performed, in most of the cases, without clear objectives, scientific support or assessment of the results (Vieira \& Pompeu 2001; Agostinho et al. 2004, 2007b); thus, most stocking efforts have been inadequate because this type of action demands a high level of knowledge and care to be successful (Blankenship \& Leber 1995; Cowx 1999; Molony et al. 2003). Although stocking is intended to replenish stocks that have experienced genetic and/or demographic losses, the effect of previous stocking efforts has rarely been measured. Basic bio-ecological aspects, such as the size, quantity and genetic diversity of individuals to be stocked and the selection of target species, as well as the location and time of release have been frequently neglected or not properly addressed (Vieira \& Pompeu 2001; Agostinho et al. 2004, 2007a). Ultimately, the absence or the inadequateness of monitoring has not allowed for improvements in stocking techniques, resulting in wasted efforts, resources and opportunities for over half a century.

Therefore, the study briefly analyzes the theoretical concepts and assumptions that motivate the activity, presents associated potential risks, evaluates the Brazilian experience (emphasizing reservoirs) and provides basic technical recommendations for stocking to achieve greater success and environmental responsibility. We believe that a discussion of this topic is timely because stocking actions have strong popular support and, consequently, are used inappropriately and/or opportunistically (Agostinho et al. 2005). Furthermore, it is worrisome that people without any scientific knowledge, who are often motivated by laudable, albeit erroneous, reasons, can conduct stockings at any time.

\section{Stocking Approaches}

Stocking is a method to manage fish populations management that involves the release of wild or cultivated organisms to replenish a specific stock with demographic and/or genetic restrictions (temporary stocking) or to increase the fishing yield above the one supported by natural recruitment (permanent stocking). Therefore, it can be motivated by interests in the conservation of stocks and/or biomass production for fishing.

Stocking can be classified as the following: (i) maintenance stocking, when individuals of a species are released into an area where it historically occurs naturally, but it does not have self-sustaining populations anymore; that is, there is no natural recruitment, and the stock requires periodic and ongoing releases; (ii) supplementation stocking, when the natural stock has demographic or genetic restrictions due to a variety of reasons (e.g., habitat modification, fragmentation, excessive fishing, and natural failures in recruitment). In the first group, the interest is essentially fishing exploration. However, supplementation, if well-executed, can also serve to conservation purposes because it is implicit that natural recruitment is happening, but in low levels. In this case, the success of stocking for conservation can be measured by the proportion of individuals from the natural recruitment in the population or in the fishing, which indicates rehabilitation. There is, however, a continuum between supplementation and maintenance stocking, i.e., between interests that are strictly for conservation and those that are for fishing exploration. Because maintenance stocking is based on non-sustainable populations and is implicit continuity, it can be considered as ex-situ conservation in reservoir.

In a broad sense, stocking can also be classified as (iii) addition or introduction, when it involves the release of a species into an area where it does not occur naturally but where it can, however, establish a self-sustaining population. Given the peculiarities of this stocking approach, it will not be discussed in this article (For more details on the subject, see Agostinho et al. 2007a).

Other recurring terms for stocking are given by Cowx (1994, 1999), such as stocking for mitigation (voluntary or mandatory to attenuate or compensate for damage produced in the environment), stocking for enhancement (improve the fishing yield), stocking for restoration (complement other management actions designed to remove or reduce factors that limit stocks), creation of new fisheries (addition or introduction of new species).

In the case of large impoundments, where the impact on ichthyofauna is relevant, even stocking that is performed to improve fishing should not, for ethical reasons, disregard conservation interests.

\section{Potential Impacts}

As any management action, fish stocking can carry some environmental risks that can reach tragic proportions if conducted carelessly. The potential impacts of stocking include: the introduction of non-native species of fish, even by stockings that are not for that purpose; dissemination of pathogens and parasites; deleterious effects related to the genetic quality of matrices and fingerlings (bottleneck effects, loss of genetic variability and fitness, domestication); and impacts on the structure and functioning of communities (intra- and interspecific competition, predation) (Figure 1).

Hydrological changes, which are inevitable in impoundments, along with introduced species, are currently the main threats to freshwater biota (Cambray 2003; Eby et al. 2006; Rahel 2007; Johnson et al. 2008; Vitule et al. 2009). Paradoxically, 
the stocking of exotic species was one of the strategies used to mitigate impacts arising from the impoundments. Because stocking with non-native species in public waters is illegal and blatantly contradicts the commitments made by countries that signed the Convention on Biodiversity, including Brazil, which promulgated it as law, this approach of fishing management will not be discussed in this article. In any case, the problems with predation, competition, parasitism, habitat changes and genetic degradation due to stocking with non-native species are widely discussed in the literature (Zaret \& Paine 1973; Santos et al. 1994, 2001; Gabrielli \& Orsi 2000; Vieira \& Pompeu 2001; Gomieiro \& Braga 2004; Canonico et al. 2005; Agostinho et al. 2007a; Resende et al. 2008; Latini \& Petrere 2004; Fugi et al. 2008; Pelicice \& Agostinho 2009). The introduction of pathogens and parasites during the process of stocking is not any less problematic for conservation; these invaders are introduced by the water used for transportation and through infected fish released in the environment (Molony et al. 2003 and citations therein).

Genetic losses, although they have not been well researched in Brazilian reservoirs (for an exception, see Matsumoto \& Hilsdorf 2009; Rodriguez-Rodriguez et al. 2010), have been considered among the most common and deleterious effects of the process of stocking (Hindar et al. 1991; Ford 2002; Araki et al. 2007) and can compromise the viability of wild populations in the short and long term (on ecological and evolutionary scales, respectively). These findings clash with public opinion, which regards the release of the fish as an inexorably positive event that can only help the recovery of the environment.

In Brazil, the operational rules for the production of fingerlings for stocking are, frequently, the same used for their production for fish farming, and this production is, in general, implemented concurrently in the same hatchery. However, it should be noted that changes in gene frequencies are inevitable in the manipulation of breeding and rearing of wild animals in captivity. These changes, which are well documented for domestic livestock, arise from the breeding of individuals with a high degree of parentage and/or reduced effective population size (inbreeding), the crossing of genetically divergent fish (outbreeding), or artificial gene selection by favoring characteristics adapted to the rearing environment either during the maintenance of breeders or during the development of eggs, larvae and fingerlings (domestication; Flagg \& Nash 1999).

Therefore, the selection of breeders based on traits linked to the production in fish farms or maintenance of a reduced group for a prolonged time can contribute to the homogenization of the cultivated stock, distancing it from the wild gene pool (inbreeding). The genetic variability of the broodstock, which is usually very low (Calcagnotto \& Toledo-Filho 2000), leads to reduction in the genetic variability of the wild population when continuous stocking is performed, because gene exchange between the groups is inevitable. In cultivation, it is also common the broodstock be close relatives of each other and this can increase the incidence of anomalies in the development of fingerlings, as well as interfere in the survival rate and growth rate of the fish. As the environmental pressures in captivity greatly differ from the pressures to which fish are subjected under natural conditions, the production of some generations in captivity is enough to alter the gene pool of the domesticated group and, consequently, to reduce its biological performance in the natural environment (Ford 2002; Caroffino et al. 2008). All of this indicates that, if there is gene exchange between domesticated and wild fish, the sustainability of the population will be negatively affected (Hansen 2002).

The production and stocking of a given species in a basin from breeders obtained in another basin was a common procedure in Brazil until recently. Although the effects of this stocking have not been investigated, it is known that spatially isolated populations that are subjected to different selective pressures can, during the evolutionary process, have a gene pool that is adapted to local conditions, albeit with potentially poor performance in another basin, even if it is within the area of natural distribution of the species. The release of individuals from naturally distinct populations leads to the problem of outbreeding depression because it affects the viability and fertility of the receiving population, decreasing the fitness of individuals. Reproduction with individuals from remote populations can dilute the effects of locally advantageous alleles through the influx of new alleles; this possibility is especially critical if this event affects co-adapted "gene complexes" (combination of locally adapted genes). For example, hybrids of pink salmon Oncorhynchus gorbuscha were made between females from Auke Creek (Alaska) and Pillar Creek (Kodiak Island) using as control, crossing between males and females of the same creek. Parentage assignment from microsatellite analysis was used to improve estimates of survival. The hybridization reduced return rates of adults in the $\mathrm{F} 1$ generation and decreased the survival in F2 (Gilk et al., 2004). The crossing among populations of largemouth bass (Micropterus salmoides) from different basins (Mississippi River basin X Great lakes basin) also showed the effect of outbreeding depression. The increasing in the mortality rate was 3.6 times more in the generation F2 than in F1 and in native fishes, caused by susceptibility to infectious disease (Goldberg et al. 2005)

Finally, it is worth noting that knowledge of the carrying capacity of the environment and of the size of the wild stock are basic concepts that should guide the need for stocking (Cowx 1999). However, these aspects have been systematically ignored by stocking programs, based on the rationale that the addition of fish to the system is always beneficial to fishing practices (Agostinho et al. 2008). In the case in which the environment does not support a surplus population, there is a risk of strong demographic changes (Molony et al. 2003; van Zyll de Jong et al. 2004). The added contingent can compete with the resident fish (Vehanen et al. 2009), increasing the mortality rate, decreasing the growth rate or leading to resource depletion. If the stocked species is a predator, 
there is risk of an exacerbated increase in the consumption of native invertebrates and fish, altering the organization of trophic webs (Skov et al. 2002). There is no evidence that these problems are occurring in Brazilian reservoirs due to a lack of relevant research and monitoring. Nevertheless, considering that reservoirs have their carrying capacities determined by the littoral zone, which is proportionally small when compared to the entire reservoir surface, (Agostinho et al. 1999), there is an increased risk that the ecological interactions intensify via stocking.

\section{The Brazilian Experience}

The first stockings in public waters in Brazil were conducted in the Northeast by the "Comissão Técnica de Piscicultura do Nordeste" (Technical Commission on Pisciculture of the Northeast), which was later called the "Diretoria de Pesca e Piscicultura do Departamento Nacional de Obras Contra as Secas" - DNOCS (Board of Fishing and Pisciculture of the National Department of Works Against Drought - DNOCS), more specifically on August 14, 1933, in the Campos da Sementeira Dam, in the town of Arcoverde, in Pernambuco State (Gurgel \& Nepomuceno 1988). Repeated stockings in this region obtained self-sustaining populations of non-native species, and improved fish yield, especially for tilapias (Paiva et al. 1994). The Northeast strategy, especially with non-native species, has disseminated to other regions in Brazil and became the main fishing management method practiced by fishery development agencies and hydroelectric power companies throughout the $20^{\text {th }}$ century. However, many of these were inefficient or constituted an additional threat to biodiversity (Agostinho et al. 2004, 2007b).

In the other regions of Brazil, stockings were usually considered as part of initiatives to mitigate the impacts of dams on fishing resources, and they were supported by positive public opinion (common sense) and had a strong political-electoral appeal (Agostinho et al. 2005). This same common sense explains the popular acceptance of stocking as a compensatory measure for impacts and the compulsory character of its use as a punishment in cases of environmental law offenses. Stocking activities are also common as part of holiday celebrations because they are considered an important strategy for environmental education.

Until 1990, non-native species were predominant in stocking programs in the South and Southeast regions of Brazil. Under the claim that urgent measures should be taken and that they could not wait for the results of the study with native species, more than one dozen species of fish from other basins, including other continents, were stocked in reservoirs (Agostinho et al. 2007a). Some of them achieved success in colonization and are currently disseminated in these basins (e.g. Plagioscion squamosissimus and Cichla spp.), while others, although not disseminated, are locally abundant (e.g., tilapias, Astronotus and Triportheus). Monitoring data on commercial fishing landings in reservoirs where exotic species were stocked showed, however, that there was no relationship between the stocking effort with these species and the fishing yield; greater yields had actually arisen from native species that had not been the object of stocking (Companhia de Energia do Estado de São Paulo 1996; AES Tiête 2007). These results caused the use of non-native species to be considered inadvisable in events promoted by the "Comitê Coordenador das Atividades de Meio Ambiente do Setor Elétrico Brasileiro" (Coordinating Committee for Environmental Activities of the Brazilian Electricity Sector; see a summary in Reuniões Temáticas: ações em http://www. eletrobras.com/elb/data/Pages/LUMIS187BD838PTBRIE. $\mathrm{htm})$, while stocking with native species was recommended, albeit with reservations.

Stocking actions in Brazil were historically performed based on limited knowledge both of the system to be managed and of the species to be stocked, as well as the need for this action. Furthermore, inexperience in conducting the stocking (species and quantity needed, as well as the location, size and time of release, etc.) led to the practice of "trial and error"; however, without monitoring it was not possible to learn from these practices (Gomes et al. 2004; Agostinho et al. 2004, 2007a; Pelicice et al. 2009). Therefore, neglecting the genetic quality of breeders and the possibility of negative impacts on natural populations has made this management activity a potential and constant threat to local populations and to fishing itself - although such consequences have never been assessed by empirical studies.

Data from Quirós (1999) on stocking rates and yields in more than 700 ponds, reservoirs and lakes around the world show that, for large reservoirs, where stocking is generally supplementary, the yield is naturally low and the response to this effort is of little relevance. Although this author does not emphasize this fact, the comparison of large and small reservoirs from the Upper Paraná River basin shows similar tendencies (AES Tietê 2007). According to Quirós (1999), small and medium sized reservoirs that presented high yields were stocked with densities between 500 and 800 ind.ha ${ }^{-1}$.year ${ }^{-1}$. In reservoirs from the Paraná River basin, this value varied between 6 and 30 ind.ha $^{-1}$.year ${ }^{-1}$, that is well below what is needed. Therefore, a large reservoir, like Água Vermelha (64,700 ha), in the Grande River basin, should have a carrying capacity proportionally similar to that of a medium or small reservoir, and should be stocked with 32 to 52 million fingerlings per year, to show a satisfactory response to the stocking effort. The number of fingerlings from three species released in this reservoir for a decade was approximately one million (AES Tietê 2007). Considering that Brazil has 3,400,000 ha of impounded water (Agostinho et al. 2007a), the quantity of fingerlings to be produced would be unreachable, and attempts to reach this number could have severe environmental consequences. In the Upper Paraná River, more promising results have been registered in reservoirs with smaller areas, with a relationship between the quantity of stocked individuals and the fishing yield, as observed for Piaractus mesopotamicus 
(Pacu), Prochilodus lineatus and Leporinus elongatus, in some reservoirs located in the Pardo River (AES Tiête 2007). Nevertheless, positive responses to the stocking effort were only apparent when the weight of released fingerlings increased from 8 to $25 \mathrm{~g}$ for P. mesopotamicus and from 6 to $18 \mathrm{~g}$ for P. lineatus (Belmont et al. 2004).

However, the carelessness in or lack of assessment of stocking results is the main factor that enabled innocuous programs to persist for more than 50 years and perpetuate the waste of resources, efforts and opportunities, as shown by the low fishing yields in Upper Paraná River reservoirs and the precarious conservation state of stocks in the main tributaries of this stretch of the river.

\section{Strategies For Stocking}

Given the irreversible character of many of the effects of impoundment on the ichthyofauna (Agostinho et al. 2008), it is expected that the discussions about the need for stocking in reservoirs will extrapolate the economic and social dimensions, and it will be necessary to effectively consider the ecological dimension. Special care is expected in the prevention of potential impacts that the stocking actions may promote. An environmentally friendly, economic and socially desirable stocking strategy should consider a sequence of procedures in which prerequisites cannot be ignored and reliable prior knowledge is essential. The minimum background information needed to the stocking process is shown in Figure 2.

\section{Deciding process}

The first requirement to decide to use stocking must be the evaluation of need, followed by economic, social and environmental viability. This decision requires comprehensive knowledge of all system components (environment, fish population, fishermen, risks, etc. - Figure 2), including environmental or artificial factors that lead to stock or population depletion.

During the discussions that precede the stocking decision, clear and quantifiable objectives must be outlined to provide

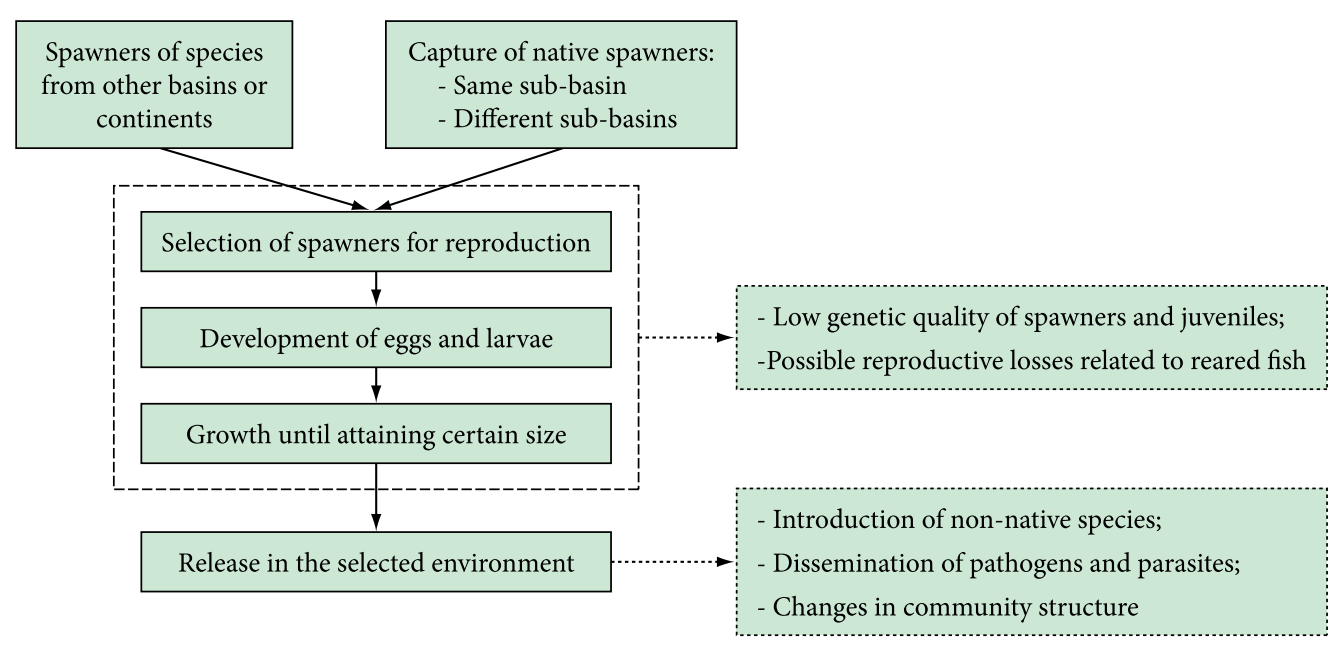

Figure 1. Summarized representation of the entire stocking process, showing the main impacts (dashed diagrams on the right) discussed in the text.

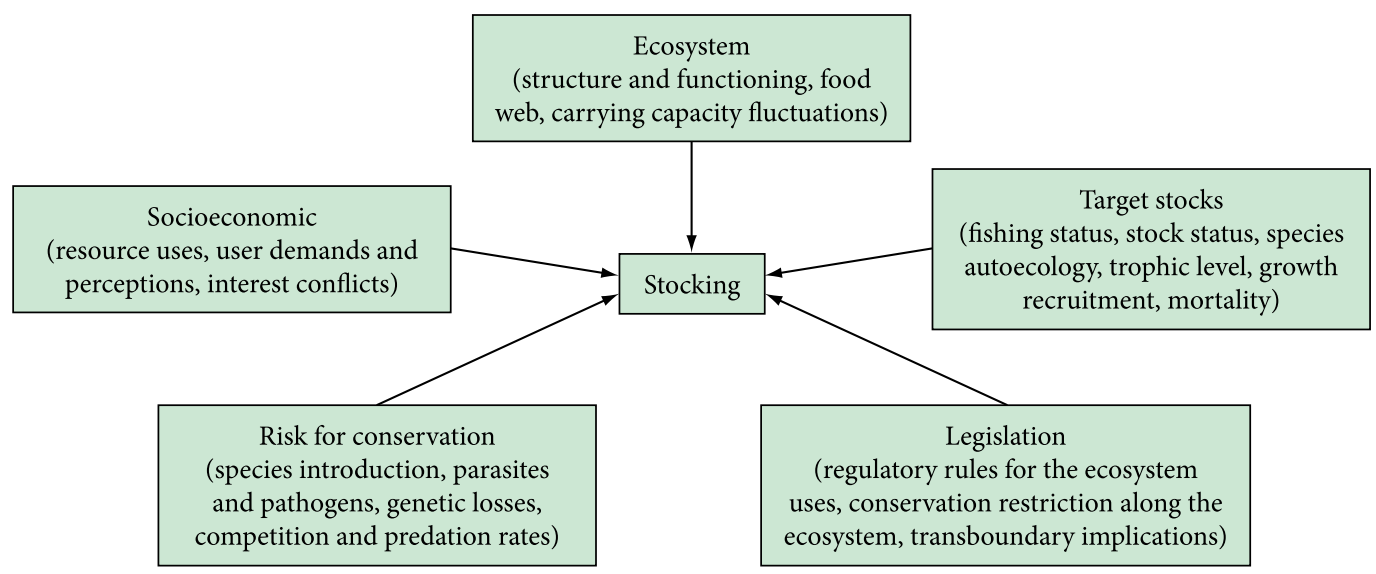

Figure 2. A conceptual model showing the complex information needed to conduct sound stocking. 
criteria for the evaluation of its effectiveness. Thus, it is of fundamental importance to consider other management strategies (e.g., fisheries control, habitat management or doing nothing; Agostinho et al. 2007a) and to consistently establish the reasons for stocking.

Although the depletion of a given population or stock can require management measures, the option for stocking may be necessitated in particular cases, such as events of increased mortality due to fishing (overfishing) or failures/insufficiencies in recruitment (due to climate issues, degradation in spawning and initial development habitats). The increase in carrying capacity due to input of nutrients (eutrophication) can also indicate a situation in which stocking may be recommended. The assessment of stocking viability requires, besides the knowledge of the factors that limit the stock, the recognition that only some stocks and environments have the potential to respond to the stocking effort and that the impacts of this activity on the target stock and the ecosystem can be high and, sometimes, irreversible (changes in community structure, disease dissemination and losses of genetic integrity; Cowx 1999). Therefore, decisions on conducting stocking are not easy. Below, we present a diagram to subsidize these decisions (Figure 3).

\section{Hatchery}

Ideally, hatcheries should be defined as recommended by Flagg \& Nash (1999), that is, facilities designed to breed and disseminate a stock of fish with genetic resources equivalent to the native stock and with an unaltered ability to naturally reproduce in its original habitat. These authors believe that this notion of a hatchery still does not exist in the world and suggest that the great challenge is to match fish production strategies with those that reduce the risk of supplementary stocking. Therefore, the success of stocking and its ecological viability are intricately linked to how the fish in this method of management are produced. The genetic effects of domestication on the reduction of the reproductive capacity of species has been analyzed by Araki et al. (2007), who estimated this reduction to be around $40 \%$ per captive-reared generation when fish are released in the natural environment. Therefore, the environmental responsibility that must guide stocking programs recommends that some guidelines should be adopted by managers to operate hatcheries, especially those indicated by Flagg \& Nash (1999), namely:

- to provide fish with minimal genetic divergence from their natural counterparts to maintain the long-term

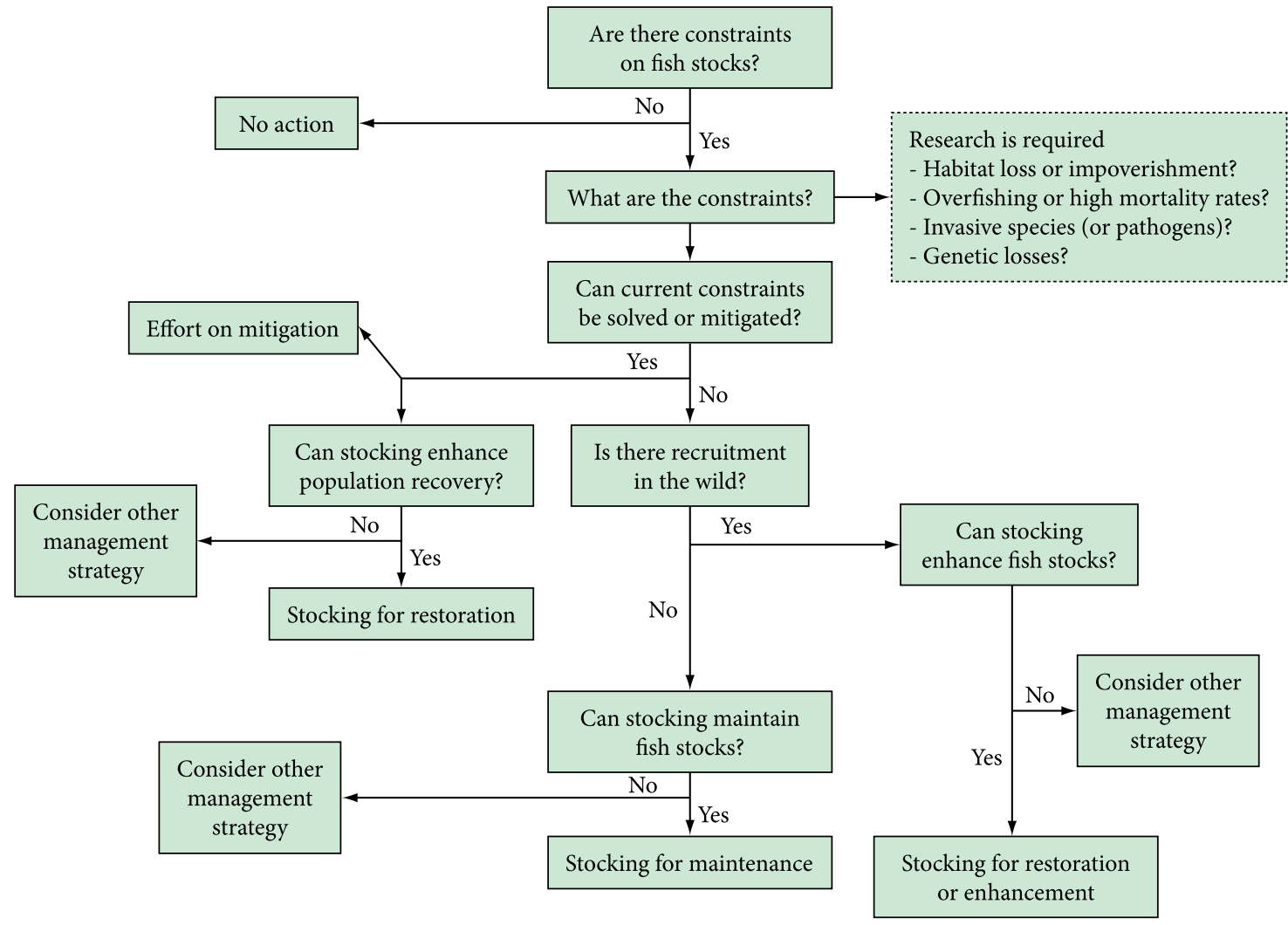

Figure 3. A decision diagram showing the links among all types of stocking, which may serve has guidelines for decision on conducting or not conducting stocking. 
adaptive characteristics, using a group of regional breeders that is sufficiently diversified;

- to manage the broodstock to maintain the natural seasonality of gonadal maturation events, ensuring high quality gametes and minimizing the early maturation of males;

- to manage the incubation process and the characteristics of the incubator, there must be options to comply with the complexity of the habitat to produce fish without selection, and with natural appearances and behaviors, as well as high survival rates;

- to establish specific targets for growth patterns that are similar to the natural patterns;

- to use low densities of fish in the production process to improve survival and avoid selection; and

- to have the option of applying anti-predatory conditioning methods during the production of fingerlings and juveniles.

We do recognize that it is difficult to follow all the guidelines presented above, but managers must pursue achieving them.

\section{Releasing}

Among the factors that have received little attention in stocking programs are those related to the quantity and size of the fish to be released, as well as the location and time of release. In an ideal situation, these variables would be defined based on knowledge of the life cycle, distribution and structure of the natural population, ideally after pilot studies (Molony et al. 2003). Therefore, the size of the fish to be released must be defined within the series of sizes registered in the wild population, except for cases in which the wild population is facing imminent extinction and requires higher survival rates (Flagg \& Nash 1999). Larger fish are more costly to produce; this expense could be compensated for by the higher survival rate after release. However, the greater time commitment required for the cultivation increased the probability of domestication selection and the development of behaviors that are not adequate for the natural environment, such as schooling, increases in naivety or loss of competiveness (Molony et al. 2003).

The choice of the release location, on the other hand, must consider information about the type of habitat in which fish from the same ontogenetic phase occur naturally, which will eventually lead to releases in distant locations from where adults occur. This also implies that release locations must not be chosen based on accessibility, a criterion that has guided stockings in reservoirs (e.g. close to bridges, beaches and margins). The time of release, which like other variables, depends on the species and its life cycle, is influenced by the size or phase in which the fish must be released. Other factors to be considered are the environmental conditions and availability of adequate food. The quantity of released fish should, ideally, be established based on the carrying capacity of the receiving body of water and avoid exceeding it. It is necessary to recognize that productivity in natural systems has limits (Wiley 1995) and that the biogenic capacity in reservoirs is usually restricted to the littoral zone. Furthermore, ecosystems are not static and instead show considerable variations in their biogenic capacities, suggesting the need to consider the fluctuations in carrying capacity to better estimate stocking effort, because these fluctuations could allow the substitution of the wild stock with the stock produced in the hatcheries (Pearsons 2010).

\section{Monitoring}

The stocking programs must be evaluated and monitored so that changes and improvements are incorporated or so that the need for abandonment is detected. Therefore, monitoring is an integral and inseparable part of the stocking action and must be clearly and consistently outlined in the decision-making stage of this mode of management. Stocking should not be considered without clearly defining the assessment method for its effectiveness and possible impacts. In this evaluation, it is crucial to distinguish and quantify the capture rate for fish from stockings and from natural recruitment, using some of the many available marking techniques (Molony et al. 2003). The monitoring of fish in hatcheries (e.g., monitoring of their genetic, morphophysiological, behavioral and health traits, in addition to their origins) and the detailed recording of the locations and dates of releases, as well as the quantity and size of released fish, are indispensable variables for explaining the results of stocking programs.

\section{Final Considerations}

Stocking has wide popular acceptance as the most complete solution for the recovery of depleted stocks. In addition to how easily understood stocking is, the interest of the media in this topic and the existence of technology for the production of a large number of fingerlings of several species contributes to this perception (Molony et al. 2003). However, studies on fish stockings in tropical reservoirs are rare in the literature and are generally restricted to cases of massive releases of fish, often including non-native species. Although this can be due to a lack of assessment of stocking for supplementation, the fact that recurring failures are not recorded needs to be considered. Given the risks associated with stocking, before this mode of management is adopted, an in-depth assessment of other alternatives is recommended (e.g., habitat management and fishing control) based on the factors that lead the stock to depletion.

When stocking method is considered appropriate and is believed to have acceptable impact levels, this strategy should be adopted in combination with improvements in the habitats and regulation of exploratory activity. The same 
way that a broad initial knowledge of the system is necessary for the decision to pursue stocking for supplementation, a detailed record and assessment of procedures are vital after implementation. Increases in fishing landings, though they may be adequate to managers and the public, cannot be used as an indication of the effectiveness of these measures from the perspective of resource conservation.

\section{Acknowledgments}

AAA and LCG thank CNPq for the Research Grant ("Bolsa Produtividade em Pesquisa") provided.

\section{References}

AES Tiête, 2007. Programa de manejo e conservação de bacias hidrográficas e reservatórios: ictiofauna e qualidade da água. Promissão, SP: Eco Consultoria Ambiental.

Agostinho AA, Miranda LE, Bini LM, Gomes LC, Thomaz SM \& Suzuki HI, 1999. Patterns of colonization in neotropical reservoirs, and prognoses on aging. In: Tundisi JG \& Straskraba M (Ed.) Theoretical Reservoir Ecology and its Applications. IIE, Brazilian Academy of Sciences. Leiden: Backhuys Publishers.

Agostinho AA, Gomes LC \& Latini JD, 2004. Fisheries management in Brazilian reservoirs: lessons from/for South America. Interciencia, 29:334-338.

Agostinho AA, Gomes LC \& Pelicice FM, 2007a. Ecologia e Manejo dos Recursos Pesqueiros em Reservatórios do Brasil. Maringá: Editora da Universidade Estadual de Maringá.

Agostinho AA, Pelicice FM \& Gomes LC, 2008. Dams and the fish fauna of the Neotropical region: impacts and management related to diversity and fisheries. Brazilian Journal of Biology, 68:1119-1132.

Agostinho AA, Pelicice FM, Petry AC, Gomes LC \& Júlio Jr HF, 2007b. Fish diversity in the upper Paraná River basin: habitats, fisheries, management and conservation. Aquatic Ecosystem Health \& Management, 10:174-186.

Agostinho AA, Thomaz SM \& Gomes LC, 2005. Conservation of the Biodiversity of Brazil's Inland Waters. Conservation Biology, 19:646-652.

Araki H, Cooper B \& Blouin MS, 2007. Genetic effects of captive breeding cause a rapid, cumulative fitness decline in the wild. Science, 318:100-103.

Belmont RAF, Dias JHP, Bovolenta S \& Boccardo AS, 2004. Estocagem como estratégia de conservação de espécies da ictiofauna nos reservatórios de Jupiá e Três Irmãos, bacia do alto Paraná. Recife, PE. In: Seminário Brasileiro de Meio Ambiente e Responsabilidade Social no Setor Elétrico; 2004; Recife. Comitê de Estudo Desempenho Ambiental de Sistema CE - CIGRE. p. 1-4.

Blankenship HL \& Leber KM, 1995. A responsible approach to marine stock enhancement. American Fisheries Society Symposium, 15:167-175.

Calcagnotto D \& Toledo-Filho SA, 2000. Loss of genetic variability at the transferrin locus in five hatchery stocks of tambaqui (Colossoma macropomum). Genetics and Molecular Biology, 23:127-130.
Cambray JA, 2003. Impact on indigenous species biodiversity caused by globalization of alien recreational freshwater fisheries. Hydrobiologia, 500:217-230.

Canonico GC, Atherington A, McCrary JK \& Thieme ML, 2005. The effects of introduced tilapias on native biodiversity. Aquatic Conservation, 15:463-483.

Caroffino DC, Millar LM \& Kapuscinski AR, 2008. Stocking success of local-origin fry and impact of hatchery ancestry: monitoring a new steelhead (Oncorhynchus mykiss) stocking program in a Minnesota tributary to Lake Superior. Canadian Journal of Fisheries and Aquatic Sciences, 65:309-318.

Companhia de Energia do Estado de São Paulo - CESP, 1996. Aspectos Limnológicos, Ictiológicos e Pesqueiros de Reservatórios da CESP no período de 1986 a 1994. São Paulo: CESP. 81 p.

Cowx IG, 1994. Stocking strategies. Fisheries Management and Ecology, 1:15-30.

Cowx IG, 1999. An appraisal of stocking strategies in the light of developing country constraints. Fisheries Management and Ecology, 6:21-34.

Eby LA, Roach WJ, Crowder LB \& Stanford JA, 2006. Effects of stocking-up freshwater food webs. Trends in Ecology of Evolution, 21:576-584.

Fernando CH \& Holcik J, 1991. Fish in reservoirs. Internationale Revue der gesamten Hydrobiologie und Hydrographie, 76:149-167.

Flagg TA \& Nash CE, 1999. A conceptual framework for conservation hatchery strategies for Pacific salmonids. U.S. Dep. Commer. 54 p. NOAA Tech. Memo. NMFS-NWFSC-38.

Ford MJ, 2002. Selection in captivity during supportive breeding may reduce fitness in the wild. Conservation Biology, 16:815-825.

Fugi R, Luz-Agostinho KDG \& Agostinho AA, 2008. Trophic interaction between an introduced (peacock bass) and a native (dogfish) piscivorous fish in a Neotropical impounded river. Hydrobiologia, 607:143-150.

Gabrielli MA \& Orsi ML, 2000. Dispersão de Lernaea cyprinacea (Linnaeus)(Crustacea, Copepoda) na região norte do Estado do Paraná, Brasil. Revista Brasileira de Zoologia, 17:395-399.

Gilk SE, Wang IA, Hoover CL, Smoker WW, Taylor SG, Grav AK \& Gharreta AJ, 2004. Outbreeding depression in hybrids between spatially separated pink salmon, Oncorhynchus gorbuscha, populations: marine survival, homing ability and variability in family size. Environmental Biology of Fishes, 69:287-297.

Goldberg TL, Grant EC, Inendino KR, Kassler TW, Claussen JE \& Phillip DP. 2005. Increased infectious disease susceptibility resulting from outbreeding depression. Conservation Biology, 19:455-462.

Gomes LC \& Miranda LE, 2001. Riverine characteristics dictate composition of fish assemblages and limit fisheries in reservoirs of the upper Paraná River basin. Regulated Rivers, 17:67-76.

Gomes LC, Fernandes R \& Luiz EA, 2004. Development of reservoir fisheries management in Brazil based on imported paradigms. Acta Scientiarum, 26:309-315.

Gomieiro LM \& Braga FMS, 2004. Feeding of introduced species of Cichla (Perciformes, Cichlidae) in Volta Grande 
Reservoir, River Grande (MG/SP). Brazilian Journal of Biology, 64:787-795.

Gurgel JJS \& Nepomuceno FH, 1988. Povoamento e repovoamento de reservatórios. In: Chacon JO, Nepomuceno FH, Gurgel JJ \& Farias JO. Manual sobre manejo de reservatório para a produção de peixes. Brasília: DNOCS/ FAO. (Documento de Campo, 9). Available from: <http:// www.fao.org/docrep/field/003/ab486p/AB486P07.htm\#VII>. Access in: 03 ago. 2010.

Hansen MM, 2002. Estimating the long-term effects of stocking domesticated trout into wild brown trout (Salmo trutta) populations: an approach using microsatellite DNA analysis of historical and contemporary samples. Molecular Ecology, 11:1003-1015.

Hindar K, Ryman N \& Utter F, 1991. Genetic effects of cultured fish on natural fish populations. Canadian Journal of Fisheries and Aquatic Sciences, 38:1867-1876.

Hoeinghaus DJ, Agostinho AA, Gomes LC, Pelicice FM, Okada EK, Latini JD, Kashiwaqui, EAL \& Winemiller KO, 2009. Effects of river impoundment on ecosystem services of large tropical rivers: embodied energy and market value of artisanal fisheries. Conservation Biology, 23:1222-1231.

Johnson PTJ, Olden JD \& Vander Zanden MJ, 2008. Dam invaders: Impoundments facilitate biological invasions into freshwaters. Frontiers in Ecology and the Environment, 6:357-363.

Latini AO \& Petrere Jr M, 2004. Reduction of a native fish fauna by alien species: an example from Brazilian freshwater tropical lakes. Fisheries Management and Ecology, 11:71-79.

Matsumoto CK \& Hilsdorf AWS, 2009. Microsatellite variation and population genetic structure of a neotropical endangered Bryconinae species Brycon insignis Steindachner, 1877: implications for its conservation and sustainable management. Neotropical Ichthyology, 7:395-402.

Molony BW, Lenanton R, Jackson G \& Norriss J, 2003. Stock enhancement as a fisheries management tool. Fish Biology and Fisheries, 13:409-432.

Paiva MP, Petrere Jr M, Petenate AJ, Nepomuceno FH \& Vasconcelos EA, 1994. Relationship between the number of predatory fish species and fish yield in large northeastern Brazilian reservoirs. In: Cowx I (Ed.). Rehabilitation of freshwater fisheries. Oxford: Fishing New Books. p. 120-129.

Pearsons TN, 2010. Operating hatcheries within an ecosystem context using the adaptative stocking concept. Fisheries, 35:23-31.

Pelicice FM \& Agostinho AA, 2008. Fish-passage facilities as ecological traps in large neotropical rivers. Conservation Biology, 22:180-188.

Pelicice FM \& Agostinho AA, 2009. Fish fauna destruction after the introduction of a non - native predator (Cichla kelberi) in a Neotropical reservoir. Biological Invasions, 11:1789-1801.

Pelicice FM, Agostinho AA \& Agostinho CS, 2009. Conservação da ictiofauna na área de influência de Peixe Angical e recomendações ao manejo. In: Agostinho CS, Pelicice FM \& Marques EE (Ed.). Reservatório de Peixe Angical: bases ecológicas para o manejo da ictiofauna. São Carlos, SP: RiMa. p. 165-179.

Quiros R, 1999. The relationship between fish yield and stocking density in reservoirs from tropical and temperated regions. In: Tundisi JG \& Straskraba M (Ed.). Theoretical Reservoir Ecology and its Applications. IIE, Brazilian Academy of Sciences. Leiden: Backhuys Publishers.

Rahel FJ, 2007. Biogeographic barriers, connectivity and homogenization of freshwater faunas: it's a small world after all. Freshwater Biology, 52:696-710.

Resende EK, Marques DKS \& Ferreira LKSG, 2008. A successful case of biological invasion: the fish Cichla piquiti, an Amazonian species introduced into the Pantanal, Brazil. Brazilian Journal of Biology, 68:799-805.

Rodriguez-Rodriguez MP, Lopera-Barrero NM, Ribeiro RP, Povh JA, Vargas L, Sirol RN \& Jacometo CP, 2010. Diversidad genética de piracanjuba usada en programas de repoblación con marcadores microsatélites. Pesquisa Agropecuária Brasileira, 45:56-63.

Santos GB, Maia-Barbosa PM, Vieira F \& López CM, 1994. Fish and zooplankton communities structure in reservoirs of southeastern Brazil: Effects of the introduction of exotic predatory fish. In: Pinto-Coelho RM, Giani A \& von Sperling $\mathrm{E}$ (Ed.). Ecology and human impact on lakes and reservoirs in Minas Gerais with special reference to future development and management strategies. Belo Horizonte: Segrac. p. 77-83.

Santos LN, Gonzalez AF \& Araujo FG, 2001. Dieta do tucunaréamarelo Cichla monoculus (Bloch \& Schneider) (Osteichthyes, Cichlidae), no Reservatório de Lajes, Rio de Janeiro, Brasil. Revista Brasileira de Zoologia,18:191-204.

Skov C, Perrow MR, Berg S \& Skovgaard H, 2002. Changes in the fish community and water quality during seven years of stocking piscivorous fish in a shallow lake. Freshwater Biology, 47:2388-2400.

Van Zyll de Jong MC, Gibson RJ \& Cowx IG, 2004. Impacts of stocking and introductions on freshwater fisheries of Newfoundland and Labrador, Canada. Fisheries Management and Ecology, 11:183-193.

Vehanen T, Huusko A \& Hokki R, 2009. Competition between hatchery-raised and wild trout Salmo Trutta in enclosures - do hatchery releases have negatives effects on wild populations? Ecology of Freshwater Fish, 18:261-268.

Vieira F \& Pompeu OS, 2001. Peixamentos - uma alternativa eficiente? Ciência Hoje, 30:28-33.

Vitule JRS, Freire CA \& Simberloff D, 2009. Introduction of non native freshwater fish can certainly be bad. Fish and Fisheries, 10:98-108.

Volpato GL, Barreto RE, Marcondes AL, Moreira PSA \& Ferreira MFB, 2009. Fish ladder select fish traits on migration - still a growing problem for natural fish populations. Marine and Freshwater Behaviour and Physiology, 42:307-313.

Wiley RW, 1995. A common sense protocol for the use of hatchery-reared trout. American Fisheries Society Symposium, 15:465-471.

Zaret TM \& Paine RT, 1973. Species introduction in a tropical lake. Science, 182:449-455. 